\title{
Tumour necrosis factor- $\alpha$ levels are elevated in adolescent patients with juvenile idiopathic arthritis on etanercept therapy
}

\author{
Anna Radziszewska*, Corinne Fisher, Linda Suffield, Geevithan Kumaran, Debajit Sen, Yiannis Ioannou \\ From 21st European Pediatric Rheumatology (PReS) Congress \\ Belgrade, Serbia. 17-21 September 2014
}

\section{Introduction}

The use of etanercept, a tumor necrosis factor (TNF) inhibitor, has revolutionized the treatment of juvenile idiopathic arthritis (JIA). TNF is a key cytokine implicated in the pathogenesis of inflammatory arthritis and etanercept, which is a soluble TNF receptor fusion protein, binds and inactivates TNF- $\alpha$ and lymphotoxin-A.

\section{Objectives}

The aim of this study was to profile serum levels of TNF- $\alpha$ in a large cohort of adolescent patients with JIA.

\section{Methods}

Serum TNF- $\alpha$ was measured in samples derived from 200 adolescent and young adult patients with JIA attending the adolescent and young adult rheumatology clinic at University College London Hospital using a commercial enzyme linked immunosorbent assay (ELISA) kit (eBioscience). Samples were tested in duplicate. Median age at sampling and median disease duration were 18 years and 8 years 9 months, respectively. Male:female ratio was 1:1.2. Equal numbers of patients with polyarticular $(n=64)$ and enthesitis related arthritis (ERA, $n=64)$ were tested in addition to 48 with oligoarticular, 16 systemic onset, and 8 psoriatic arthritis. Erythrocyte sedimentation rate (ESR) and C-reactive protein (CRP) measurements were also collected. Furthermore, an L929 cell viability bioassay was used to determine if the addition of etanercept abrogates the cytotoxic effects of TNF- $\alpha$ in L929 cells.

Arthritis Research UK Centre for Adolescent Rheumatology at University College London, Great Ormond Street Hospital and UCLH, University College London, London, United Kingdom (http://creativecommons.org/publicdomain/zero/1.0/) applies to the data made available in this article, unless otherwise stated. 
treatment is so strong, we hypothesise that it may be possible to measure TNF- $\alpha$ levels as a surrogate marker of adherence to this drug in this cohort of patients where adherence to medication can be a significant problem. This is a hypothesis that warrants further investigation.

\section{Disclosure of interest}

None declared.

Published: 17 September 2014

doi:10.1186/1546-0096-12-S1-P128

Cite this article as: Radziszewska et al:: Tumour necrosis factor- $\alpha$ levels are elevated in adolescent patients with juvenile idiopathic arthritis on etanercept therapy. Pediatric Rheumatology 2014 12(Suppl 1):P128.

Submit your next manuscript to BioMed Central and take full advantage of:

- Convenient online submission

- Thorough peer review

- No space constraints or color figure charges

- Immediate publication on acceptance

- Inclusion in PubMed, CAS, Scopus and Google Scholar

- Research which is freely available for redistribution

Submit your manuscript at www.biomedcentral.com/submit 